\title{
Eliminating the Detrimental Psychological and Physical Effects of Poverty to Promote Student Success
}

\section{Elizabeth Rodriquez ${ }^{\star}$}

Department of Behavioral and Social Sciences, Amarillo Community College, Amarillo, TX 79109, USA

\begin{abstract}
The culture of community colleges has shifted and all higher educational institutions are encountering new students with new problems. The new college students bring with them barriers that interfere with their much needed success to better their future and our country as a whole. If we can find ways to break down those barriers and help students succeed we can see students and our communities thrive. One of the major barriers we have encountered is poverty. Poverty brings about a variety of issues that limit the success of student in college such as food and home insecurity, inexperience with college ideology, unawareness of ways to help financially with school and life, and lack of support [1]. Amarillo College has become part of a "No Excuses University" to help our students remove barriers to obtain success. Some of the initiatives include coaches and champions mentoring program, addition of an advocacy center which includes multi-campus supply pantries, hands on FAFSA events on the college campus as well as in the high schools in the community and multiple partnerships that solidify our transfer students' pathways onto four year universities. One of major changes here at Amarillo College that has yielded the highest rates of success is the change to eight week courses. We have addressed mental and legal service issues by developing an Amarillo College Counseling Center and Legal Aid center which is free to students. We have also established an on campus affordable daycare center for students to take their kids while they attend class. Each initiative that we have put forth has shown promise and our success rates have increased. The next step would be to find out which of the initiatives is the true barrier breaker in order to stream line our approach to promoting optimal student success.
\end{abstract}

As each year passes, the community college dynamic changes and forces us as educators to change with it. At Amarillo Community College we have opened our eyes to a new type of student that not only needs our education but also needs our guidance to help remove barriers that prevent them being successful individuals. Our typical student at Amarillo Community College is a first generation college student, living below the poverty line, is enrolled in developmental courses, is working a full time job and supporting a family. This mean that no one else in their family has been to college so the college life is unfamiliar to them except what stereotypes that are out there, it also means that these students often have to choose between food, bills, college and work and they are not the only ones that suffer or benefit form the choices that are made. As a college we knew we needed to change and so we took steps to remove barriers such as poverty to help our student become successful and complete. In the following article I will discuss the steps that Amarillo College took to address our student's needs. I will report some data that the college data specialist, Collin Witherspoon, presented in order to show the success of our efforts.

Through our leadership, Amarillo College decided we needed to first try and learn about the major issues facing $61 \%$ of our student population. We needed to understand poverty. The first step in our journey leads us to Donna Beegle. As a college we experienced the mission Dr. Beegle followed to land her success. She too came from poverty in fact she came from generational poverty. Donna saw way out, but confronted major setbacks on her path. She elaborated

\section{Publication History:}

Received: June 24, 2018

Accepted: July 24, 2018

Published: July 26, 2018

\section{Keywords:}

Community Colleges, Stereotypes, Leadership, Poverty

on her struggles and this set us on our path in hopes of removing these obstructions to see our student succeed much like Dr. Donna Beegle did. After the entire college attended this first keynote speech, many faculty and staff began moving and acting on major issues that our students were facing. Not only that, several have attended further poverty training for better understanding. Our very own college president, Dr. Russell Lowery-Hart, participated in a poverty simulation in which he forced into situations our student see every day [2]. After some foundational training we could now look forward and take the next steps to improve our students' success. We needed to know what exactly our students required in order to focus on college. Here are the top ten needs they listed: career and employment services, childcare, food housing, counseling services, legal services, school needs, transportation, utility assistance and financial literacy. Now that we knew their needs; we have a place to start.

After careful examination, our administration realized that we could make some institutional changes that would better our students. Amarillo College already had some great fundamental programs available but we were not using them to the best of their potential. The college reorganized advising and our existing social services. The college adopted the pathway program in order to make sure that each student knew the path they needed to follow to complete an associate's degree and/or a degree for transfer. The purpose was to make sure that each student finished in a timely manner moving them to their goal of a better job sooner and to avoid taking classes that they do not need. We also developed "Success Zones". These zones are located around the campus in different areas of the college. Each zone is there to help our students in different areas that students seem to struggle such as math, science and writing. As a college we also realized that over $66 \%$ of our students were coming in designated for a developmental course which means they were not college ready. If a student is required to take more than one developmental course then it is possible that even with financial aid they could run out of money to complete a degree. This was a major problem, so some amazing

"Corresponding Author: Dr. Elizabeth Rodriquez, Department of Behavioral and Social Sciences, Amarillo Community College, Amarillo, TX 79109, USA; E-mail: e0316756@actx.edu

Citation: Rodriquez E (2018) Eliminating the Detrimental Psychological and Physical Effects of Poverty to Promote Student Success. Int J Psychol Behav Anal 4: 148. doi: https://doi.org/10.15344/2455-3867/2018/148

Copyright: (c) 2018 Rodriquez. This is an open-access article distributed under the terms of the Creative Commons Attribution License, which permits unrestricted use, distribution, and reproduction in any medium, provided the original author and source are credited. 
faculty came together to figure out how we could get students college ready. Some of the solutions included fast tracking which means that the student were meeting every day, study the subject they were not college proficient and then testing again after intense instruction. We also began linking developmental courses with "college ready" courses. I was lucky enough to part of this program and we have been linking or co-requiring developmental reading and writing with general psychology. This allows student that have not tested as college ready to take the developmental course while taking the college ready course and getting college credit so that they can get on track sooner and complete successfully with financial aid. As a college we have also transformed a majority of our courses to an 8-week format. This allows more students to become full-time students in hopes of completing more rapidly. If we can bring the light at the end of the tunnel closer, then hopefully the task does not seem as daunting. The final aspect that we enhanced was the availability of mentors. As faculty and staff at the college we each have the unique ability to help someone. We started a program called coaches and champions. Each coach, faculty or staff at Amarillo College, would have one or two champions, incoming freshman. We knew that many of our faculty already had organically grown connections with students so we just wanted to make these connections more intentional. Since the program's inception it has transformed and grown in order to reach more and more students in need. The idea is that the student has a person on campus they can go to when they have any question, any problem or just want to connect.

We didn't just stop with college. The community needed our students just as much if not more than our student needed them. Amarillo College began connecting with local work force and figuring out what we need to be preparing our student for as they begin giving back to the community and working. The Amarillo community finally realized that they had a gold mine at their fingertips and now they can get exceptional people from us doing exactly what they need to make their companies better in turn making Amarillo better as a whole. Because of the great relationships fostered by our president and other administrators, faculty and staff, Amarillo Community College is able to better leverage community resources and expand the social service program with field placement sites. As a college community we have also been able to have our student give make to the community as a whole be requiring community service hours in classes. If we help the community then the community will help us.

Next we realized that we needed to bring new programs into our institution. The college opened a new counseling center lead by Dr. Alan Kee in 2016. The ever growing need for mental health programs especially with college students illustrated the need for such a center. We are hopeful for the growth, necessity and success of this center. The college also started a free legal services center in 2016 lead by Robin Malone. The center provides students with hands on legal assistance experience, supports Amarillo college students in need and supports community members who do not typically have access to free legal advice. Another program Amarillo College began in 2016 is the advocacy and resource center lead by Jordan Herrera, we call it the ARC. The ARC is a centralized center for adult student program, social service program, food pantry, clothing closet, advising department and financial aid.

In conclusion, we know we still have areas to address such as transportation and childcare; there are ideas in the works here. We have made huge strides in removing barriers facing our students, but we will continue to search to change and to remove barriers to eliminate the detrimental physical and psychological effects of poverty to promote student success.

\section{Competing Interests}

The authors declare that they have no competing interests.

\section{References}

1. Beegle D, Ellis D, Akkary R (2007) See poverty- be the difference!. Tigard Or: Communication Across Barriers Inc.

2. Lowery-Hart R, Herrera J, Crowley C (2017) You Cannont Move the Needle Without Addressing Poverty: Building Systemic Support for Low-income Students. 